\title{
Efflux pump activity, biofilm formation and antibiotic resistance profile of Klebsiella spp. isolated from clinical samples at Lagos University Teaching Hospital
}

\author{
Sharon Akinpelu ${ }^{1}$, Abraham Ajayi ${ }^{1,2}$, Stella I. Smith ${ }^{2 *}$ and Adeyemi I. Adeleye ${ }^{1}$
}

\begin{abstract}
Objective: Nosocomial and community acquired multidrug resistant Klebsiella infections are wide spread resulting in high morbidity and mortality due to limited number of antibiotics treatment options. This study investigated efflux pump activity, biofilm forming potential and antibiotic susceptibility profile of Klebsiella spp. isolated from clinical samples in a tertiary hospital in Lagos Nigeria. Eighteen clinical Klebsiella spp. isolated from urine, blood and sputum were subjected to antibiotic susceptibility testing using the disc diffusion method. Efflux pump activity was evaluated by the ethidium bromide cartwheel method and biofilm forming ability was determined by the tissue culture plate technique.

Results: All 18 (100\%) Klebsiella isolates were resistant to cefuroxime, cefixime, amoxicillin - clavulanate, ampicillin + cloxacillin, cefotaxime, and imipenem. Seventeen (94.4\%) were resistant to ofloxacin while sixteen (88.9\%) were resistance to nalidixic acid, Gentamicin and levofloxacin. All Klebsiella isolates possessed active efflux pump with the ability to form biofilm. However, their biofilm forming capabilities varied as 4 (22.2\%) were strong, $3(16.7 \%)$ were moderate and 11 (61.1\%) were weak biofilm formers. Findings in this study reveal multiple factors at play in mediating the high level of antibiotic resistance observed in Klebsiella isolates. Hence a multifaceted approach is advocated in managing the infections caused by the pathogen.
\end{abstract}

Keywords: Efflux pump, Biofilm, Antibiotic resistance, Klebsiella

\section{Introduction}

Among pathogenic Gram-negative bacteria that belong to the family Enterobacteriaece, the genus Klebsiella consist of species known to cause community-acquired and nosocomial infections including urinary tract infections (UTIs), pneumonia, sepsis and bloodstream infection. With the emergence of antibiotic resistant and hypervirulent Klebsiella strains, infections they cause result in

\footnotetext{
*Correspondence: stellaismith@yahoo.com

${ }^{2}$ Molecular Biology and Biotechnology Department, Nigerian Institute

of Medical Research, Yaba, Lagos, Nigeria

Full list of author information is available at the end of the article
}

high morbidity and mortality majorly in high risk individuals including immunocompromised, neonates and the elderly [1-4]. Several studies have reported multidrug resistant Klebsiella strains isolated from clinical cases. Rath and Padhy [5], reported a high prevalence of multidrug resistant $K$. oxytoca and $K$. pneumonia isolated from an Indian teaching hospital and adjoining community. Strains were resistant to fluoroquinolones, carbapenem, third and fourth generation cephalosporins. In a similar study, Fadeyi et al. [6] in Nigeria reported Klebsiella spp. of clinical origin that displayed high resistance to ceftazidime $(100 \%)$, cefotaxime $(94.0 \%)$, ciprofloxacin $(70.0 \%)$ and trimethoprim-sulphamethoxazole (92.0\%). However, 
no resistance to carbapenem was recorded. Biofilm formation has been linked to antimicrobial resistance and persistence observed in several pathogenic Gram negative bacteria including Klebsiella species [7]. Biofilm is an aggregation of sessile microorganisms enclosed in a matrix of extracellular polymeric substances. Their prevalence in medical implants, living and dead tissues make infection they cause difficult and expensive to treat [8]. Another factor that mediates antibiotic resistance in bacteria is the possession of active efflux pumps. Efflux pump systems expel a large array of chemical compounds including antibiotics from bacteria cells that possess them in an energy dependent manner [9]. It has been reported that efflux pump activity is connected to biofilm formation with a whole resultant effect of amplified antibiotic resistance [8] (Reza et al. 2019). Hence this study seeks to evaluate the efflux pump activity, biofilm formation and antibiotic resistance profiles of Klebsiella spp. isolated from clinical samples in a tertiary hospital in Lagos Nigeria.

\section{Main text}

A total of eighteen Klebsiella isolates were obtained from Lagos University Teaching Hospital, Idi Araba Lagos Nigeria. Isolates were re-identified using standard biochemical tests according to Cheesebrough [10].

\section{Methodology}

Antimicrobial susceptibility testing was carried out according to European Committee on Antimicrobial Susceptibility Testing [11], guidelines using the disc diffusion method. Eleven antibiotics including cefuroxime, gentamicin, cefixime, ofloxacin, amoxicillin-clavulanate, nalidixic acid, cefotaxime, ampicilin + cloxacillin, nitrofurantoin, imipenem and levofloxacin were used. Using a sterile cotton swab, one or two colonies of isolates were emulsified in normal saline and adjusted to $0.5 \mathrm{McFar}-$ land standard which was then applied onto the surface of Muller-Hinton agar. Antibiotic discs were then applied and incubated at $37^{\circ} \mathrm{C}$ for 24 h. E. coli ATCC 25922 was used as for quality control.

Efflux pump activity of isolates was determined according to the method of Martins et al. [9] using the ethidium bromide (EtBr) cartwheel method. Cell suspension of isolates with approximately $10^{6}$ cells per $\mathrm{mL}$ were streaked on Muller-Hinton agar plates containing $0 \mathrm{mg} / \mathrm{L}$, $0.5 \mathrm{mg} / \mathrm{L}, 1 \mathrm{mg} / \mathrm{l}, 1.5 \mathrm{mg} / \mathrm{L}$ and $2 \mathrm{mg} / \mathrm{L}$ concentrations of $\mathrm{EtBr}$ and incubated at $37{ }^{\circ} \mathrm{C}$ for $24 \mathrm{~h}$. After which bacteria culture were viewed under a UV trans-illuminator (Cleaver Scientific Ltd) for fluorescence. Agarose gels that contained $\mathrm{EtBr}$ were dried and put in plastic bags which were then collected by the waste disposal unit for onward disposal.
Ability of isolates to form biofilm was determined by the tissue culture plate technique of Stephanovic et al. [12]. Single colonies of each Klebsiella isolate were inoculated into brain heart infusion (BHI) broth (Oxoid, Basingstoke, UK) supplemented with $2 \%$ sucrose and 200 $\mu \mathrm{L}$ of bacterial suspension was loaded into the individual wells of 96-well microtiter plate. Two hundred microlitre of sterile BHI broth was used as negative control. After $24 \mathrm{~h}$ incubation at $37{ }^{\circ} \mathrm{C}$ content of each well was discarded and wells were washed three times with sterile deionized water to remove non-adherent bacteria. Wells were air-dried for $45 \mathrm{~min}$ and $200 \mu \mathrm{L}$ of $0.1 \%$ (v/v) crystal violet solution was added to each well and incubated for $45 \mathrm{~min}$ at room temperature then wells were again washed four times with sterile deionized water. Thirtythree percent glacial acetic acid was added to wells to solubilize incorporated dye. The optical density (OD) of stained adherent bacteria was measured at $650 \mathrm{~nm}$ using the Emax ${ }^{\circledR}$ Plus Microplate Reader (Molecular Devices San Jose, CA). The assay was performed in triplicate.

\section{Results}

All eighteen (100\%) Klebsiella isolates showed resistance to cefuroxime, cefixime, amoxicillin - clavulanate, ampicillin + cloxacillin, cefotaxime, and imipenem. Seventeen (94.4\%) were resistant to ofloxacin while sixteen (88.9\%) were resistance to nalidixic acid, gentamicin and levofloxacin. Only thirteen (72.2\%) were resistant to nitrofurantoin as shown in Fig. 1.

All Klebsiella spp. isolates were positive for efflux pump activity as they fluorescence under UV light at $0.5 \mathrm{mg} / \mathrm{L}$ $\mathrm{EtBr}$ concentration. However only four $(22.2 \%)$ were strong biofilm formers, while three (16.7\%) and eleven

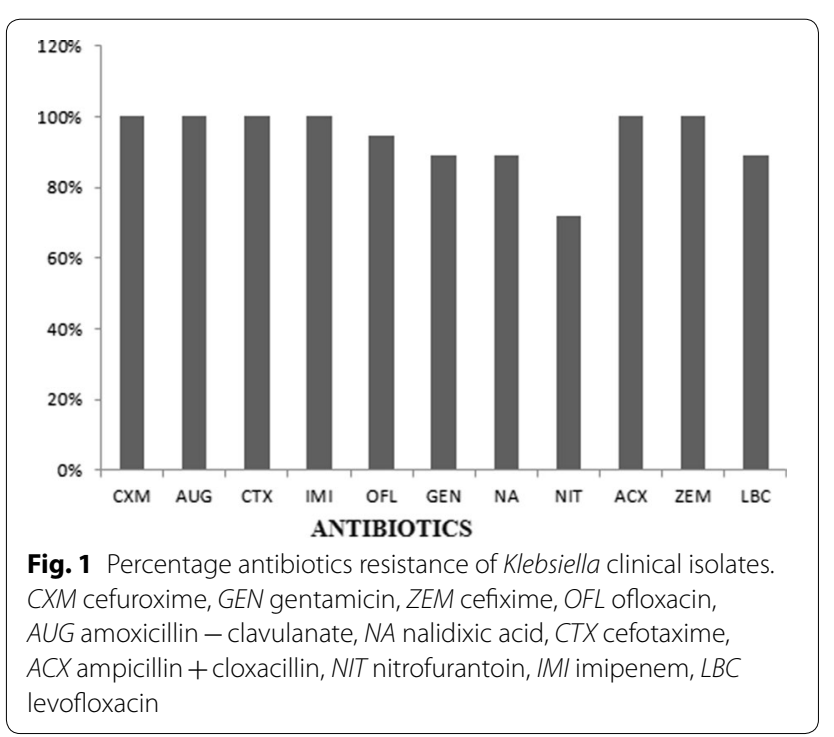


(61.1\%) were moderate and weak biofilm formers respectively. All strong biofilm formers were Klebsiella spp. isolated from urine, though others also isolated from urine were are moderate and weak biofilm formers as shown in Table 1.

Two isolates (K51 and K68) that were strong biofilm formers and exhibited efflux pump activity displayed pan resistance to all eleven test antibiotics. Although isolates K52, K53, K59 isolated from urine and isolates K63, K64 isolated from sputum that were weak biofilm formers with efflux pump activity were also resistant to all eleven test antibiotics.

\section{Discussion}

Hospital and community acquired infections caused by Klebsiella spp. are wide spread and are becoming difficult to treat due to antibiotic resistance and biofilm formation ability of this pathogen $[13,14]$. In this study Klebsiella spp. isolated from urine, blood and sputum showed high (100\%) resistance to cefuroxime, cefixime, amoxicillin - clavulanate, ampicillin + cloxacillin, cefotaxime, and imipenem. Previous studies in Nigeria have also documented high and extensive resistance of Klebsiella spp. to $\beta$-lactam antibiotics [15-18]. Globally, resistance of Klebsiella spp. to $\beta$-lactam antibiotics including carbapenem is rife. Huai et al. [19] reported Klebsiella pneumoniae isolates that had high rate of resistance to impenem in China. Similarly, Yazdansetad et al. [20] a $50 \%$ rate of extended spectrum $\beta$-lactamase (ESBL) producing $K$. pneumoniae in Iran. In this study Klebsiella spp. also had considerable resistance to other antibiotics including ofloxacin (94.4\%), nitrofurantoin (72.2\%) and $88.9 \%$ resistance to nalidixic acid, gentamicin and levofloxacin. This is similar to the findings of Fadeyi et al. [6] and Humayun et al. [21] that reported the resistance of Klebsiella spp. to fluoroquinolone, aminoglycoside and sulfamethoxazole in Nigeria and Pakistan respectively. Several mechanisms have been deployed overtime by bacteria pathogens in evading the action of antibiotics. One of such mechanism is possessing active efflux pumps which was detected in all Klebsiella spp. isolates investigated in this study. Thus it could be asserted that active efflux pump played a role in the observed level of antibiotic resistance. Szabo et al. [22] and Maurya et al. [23] reported the role of efflux pump in quinolone and $\beta$-lactam antibiotic resistance in Klebsiella pneumoniae strains isolated from clinical samples in Hungary and India respectively. Klebsiella spp. are known to form biofilm which enhances their virulence and resistance to antibiotics [13]. Nirwati et al. [24] reported strong (26.95\%), moderate (28.74\%) and weak (29.94\%) biofilm forming $K$. pneumonia isolates that were extensively resistant to antibiotics in tertiary care hospital in Indonesia. This is similar to our findings in this study although

Table 1 Biofilm forming potential, efflux pump activity and antibiotic susceptibility profile of Klebsiella spp

\begin{tabular}{|c|c|c|c|c|c|c|c|c|c|c|c|c|c|c|c|c|}
\hline \multirow[t]{2}{*}{ Isolate ID } & \multirow[t]{2}{*}{ Source } & \multicolumn{3}{|c|}{ Biofilm forming potential } & \multirow{2}{*}{$\begin{array}{l}\text { Efflux pump activity } \\
\text { Phenotypic }\end{array}$} & \multicolumn{11}{|c|}{ Antibiotic resistance profile } \\
\hline & & Strong & Moderate & Weak & & CXM & AUG & CTX & IMI & OFL & GEN & NA & NIT & $A C X$ & ZEM & LBC \\
\hline K51 & Urine & $\checkmark$ & & & + & $\mathrm{R}$ & $\mathrm{R}$ & $\mathrm{R}$ & $\mathrm{R}$ & $\mathrm{R}$ & $\mathrm{R}$ & $\mathrm{R}$ & $\mathrm{R}$ & $\mathrm{R}$ & $\mathrm{R}$ & $\mathrm{R}$ \\
\hline K52 & Urine & & & $\checkmark$ & + & $\mathrm{R}$ & $\mathrm{R}$ & $\mathrm{R}$ & $\mathrm{R}$ & $\mathrm{R}$ & $\mathrm{R}$ & $\mathrm{R}$ & $\mathrm{R}$ & $\mathrm{R}$ & $\mathrm{R}$ & $\mathrm{R}$ \\
\hline K53 & Urine & & & $\checkmark$ & + & $\mathrm{R}$ & $\mathrm{R}$ & $\mathrm{R}$ & $\mathrm{R}$ & $\mathrm{R}$ & $\mathrm{R}$ & $\mathrm{R}$ & $\mathrm{R}$ & $\mathrm{R}$ & $\mathrm{R}$ & $\mathrm{R}$ \\
\hline K54 & Urine & & & $\checkmark$ & + & $\mathrm{R}$ & $\mathrm{R}$ & $\mathrm{R}$ & $\mathrm{R}$ & $\mathrm{R}$ & S & $\mathrm{R}$ & $\mathrm{R}$ & $\mathrm{R}$ & $\mathrm{R}$ & $\mathrm{R}$ \\
\hline K55 & Urine & & $\checkmark$ & & + & $\mathrm{R}$ & $\mathrm{R}$ & $\mathrm{R}$ & $\mathrm{R}$ & $\mathrm{R}$ & $\mathrm{R}$ & $\mathrm{R}$ & $S$ & $\mathrm{R}$ & $\mathrm{R}$ & $\mathrm{R}$ \\
\hline K56 & Urine & & $\checkmark$ & & + & $\mathrm{R}$ & $\mathrm{R}$ & $\mathrm{R}$ & $\mathrm{R}$ & $\mathrm{R}$ & $\mathrm{R}$ & $\mathrm{R}$ & $\mathrm{R}$ & $\mathrm{R}$ & $\mathrm{R}$ & $\mathrm{R}$ \\
\hline K57 & Urine & & & $\checkmark$ & + & $\mathrm{R}$ & $\mathrm{R}$ & $\mathrm{R}$ & $\mathrm{R}$ & $\mathrm{R}$ & $S$ & $\mathrm{R}$ & $\mathrm{R}$ & $\mathrm{R}$ & $\mathrm{R}$ & $\mathrm{R}$ \\
\hline K58 & Urine & & & $\checkmark$ & + & $\mathrm{R}$ & $\mathrm{R}$ & $\mathrm{R}$ & $\mathrm{R}$ & $\mathrm{R}$ & $\mathrm{R}$ & $\mathrm{R}$ & $\mathrm{S}$ & $\mathrm{R}$ & $\mathrm{R}$ & $\mathrm{R}$ \\
\hline K59 & Urine & & & $\checkmark$ & + & $\mathrm{R}$ & $\mathrm{R}$ & $\mathrm{R}$ & $\mathrm{R}$ & $\mathrm{R}$ & $\mathrm{R}$ & $\mathrm{R}$ & $\mathrm{R}$ & $\mathrm{R}$ & $\mathrm{R}$ & $\mathrm{R}$ \\
\hline K60 & Urine & $\checkmark$ & & & + & $\mathrm{R}$ & $R$ & $\mathrm{R}$ & $\mathrm{R}$ & $\mathrm{S}$ & $\mathrm{R}$ & $S$ & $\mathrm{R}$ & $\mathrm{R}$ & $\mathrm{R}$ & $S$ \\
\hline K61 & Urine & & & $\checkmark$ & + & $\mathrm{R}$ & $R$ & $\mathrm{R}$ & $\mathrm{R}$ & $\mathrm{R}$ & $\mathrm{R}$ & $R$ & $\mathrm{~S}$ & $\mathrm{R}$ & $\mathrm{R}$ & $S$ \\
\hline K62 & Blood & & $\checkmark$ & & + & $\mathrm{R}$ & $\mathrm{R}$ & $\mathrm{R}$ & $\mathrm{R}$ & $\mathrm{R}$ & $\mathrm{R}$ & $R$ & $S$ & $\mathrm{R}$ & $\mathrm{R}$ & $\mathrm{R}$ \\
\hline K63 & Sputum & & & $\checkmark$ & + & $\mathrm{R}$ & $\mathrm{R}$ & $\mathrm{R}$ & $\mathrm{R}$ & $\mathrm{R}$ & $\mathrm{R}$ & $\mathrm{R}$ & $\mathrm{R}$ & $\mathrm{R}$ & $\mathrm{R}$ & $\mathrm{R}$ \\
\hline K64 & Sputum & & & $\checkmark$ & + & $\mathrm{R}$ & $\mathrm{R}$ & $\mathrm{R}$ & $\mathrm{R}$ & $\mathrm{R}$ & $\mathrm{R}$ & $\mathrm{R}$ & $\mathrm{R}$ & $\mathrm{R}$ & $\mathrm{R}$ & $\mathrm{R}$ \\
\hline K65 & Urine & & & $\checkmark$ & + & $\mathrm{R}$ & $\mathrm{R}$ & $\mathrm{R}$ & $\mathrm{R}$ & $\mathrm{R}$ & $\mathrm{R}$ & $\mathrm{R}$ & $\mathrm{R}$ & $\mathrm{R}$ & $\mathrm{S}$ & $\mathrm{R}$ \\
\hline K66 & Urine & & & $\checkmark$ & + & $\mathrm{R}$ & $\mathrm{R}$ & $\mathrm{R}$ & $\mathrm{R}$ & $\mathrm{R}$ & $\mathrm{R}$ & $\mathrm{R}$ & $\mathrm{R}$ & $\mathrm{R}$ & $\mathrm{R}$ & $\mathrm{R}$ \\
\hline K67 & Urine & $\checkmark$ & & & + & $\mathrm{R}$ & $\mathrm{R}$ & $\mathrm{R}$ & $\mathrm{R}$ & $\mathrm{R}$ & $\mathrm{R}$ & $\mathrm{R}$ & $\mathrm{S}$ & $\mathrm{R}$ & $\mathrm{R}$ & $\mathrm{R}$ \\
\hline K68 & Urine & $\checkmark$ & & & + & $\mathrm{R}$ & $\mathrm{R}$ & $\mathrm{R}$ & $\mathrm{R}$ & $\mathrm{R}$ & $\mathrm{R}$ & $\mathrm{R}$ & $\mathrm{R}$ & $\mathrm{R}$ & $\mathrm{R}$ & $\mathrm{R}$ \\
\hline
\end{tabular}

CXM cefuroxime, GEN gentamicin, ZEM gefixime, OFL ofloxacin, AUG amoxicillin - clavulanate, NA nalidixic acid, CTX cefotaxime, $A C X$ ampicillin + cloxacillin, NIT nitrofurantoin, IMI imipenem, $L B C$ levofloxacin 
with slight variation of having $61.1 \%$ weak biofilm formers. However it was observed that the strength of biofilm formation be it strong, moderate or weak did not exclusively influence pan resistance to all test antibiotics used. This can be related to the study of Alcántar-Curiel et al. [25] in Mexico that reported no direct association of biofilm formation and ESBL production in multidrug resistant nosocomial K. pneumonia isolates.

\section{Conclusion}

Multiple factors at play can generally amplify antibiotic resistance in bacterial pathogens as observed in this study. Hence there should be a multifaceted approach such as use of efflux pump inhibitors and biofilm disruptors in combination with antibiotic therapy in tackling the problem. Also routine surveillance should be a thing of priority in health care and community settings to curb the continuous transmission of antibiotic resistant Klebsiella spp.

\section{Limitation of study}

It would be difficult to make far reaching conclusion as the number of isolates in this study are few. Hence future study should cover more hospital and investigate a larger number of isolates.

\section{Abbreviations \\ ESBL: Extended spectrum beta lactamase; EtBr: Ethidium bromide; UV: Ultra violet; UTIs: Urinary tract infections.}

\section{Acknowledgements}

Not applicable.

\section{Authors' contributions}

Conception and design: AAI, SSI; Laboratory experiment: AS, AA; Result Analysis and manuscript writing/review: AS, AA, AAl, SSI. All authors read and approved the final manuscript.

\section{Funding}

None.

\section{Availability of data and materials}

All data obtained are available within the article.

\section{Ethics approval and consent to participate}

Ethical approval for this study was obtained from the Institutional Review Board, Nigerian Institute of Medical Research with code number IRBB/19/033.

\section{Consent for publication}

Not applicable.

\section{Competing interests}

There is no conflict of interest.

\section{Author details}

${ }^{1}$ Department of Microbiology, University of Lagos, Lagos, Nigeria. ${ }^{2}$ Molecular Biology and Biotechnology Department, Nigerian Institute of Medical Research, Yaba, Lagos, Nigeria.
Received: 26 February 2020 Accepted: 21 May 2020

Published online: 26 May 2020

\section{References}

1. Podschun R, Ullmann U. Klebsiella spp. as nosocomial pathogens: epidemiology, taxonomy, typing methods and pathogenicity factors. Clin Microbiol Rev. 1998;11(4):589-603

2. Omoregie $\mathrm{R}$, Igbarumah $\mathrm{IO}$, Egbe $\mathrm{CA}$, Ogefere $\mathrm{OH}$. Urinary tract infection among neonates in Benin City Nigeria. GMBHS. 2012;4:118-21.

3. Li J, Huang Z-Y, Y Y T, Tao X-Y, Hu Y-M, Wang HC, Zou M-X. Isolation and characterization of a sequence type 25 carbapenem-resistant hypervirulent Klebsiella pneumoniae from mid-south region of China. BMC Microbiol. 2019;19:219.

4. Bengoechea JA, Pessoa JS. Klebsiella pneumoniae infection biology: living to counteract host defenses. FEMS Microbiol Rev. 2019;43(2):123-44.

5. Rath S, Padhy RN. Prevalence of two multidrug-resistant Klebsiella species in an Indian teaching hospital and adjoining community. J Infect Public Heal. 2014:7:496-507.

6. Fadeyi A, Zumuk CP, Raheem RA, Nwabuisi C, Desalu OO. Prevalence and antibiotic susceptibility pattern of ESBL producing Klebsiellae isolated from clinical specimens in a Nigerian tertiary hospital. Afr J Infect Dis. 2016;10(1):32-7.

7. Dumaru R, Baral R, Shrestha LB. Study of biofilm formation and antibiotic resistance pattern of Gram negative bacilli among the clinical isolates at BPKIHS, Dharan. BMC Res Notes. 2019;12:38.

8. Reza A, Sutton JM, Rahman KM. Effectiveness of efflux pump inhibitors as biofilm disruptors and resistance breakers in Gram negative (ESKAPEE) bacteria. Antibiotics. 2019;8:229.

9. Martins M, Viveiros M, Couto I, Costa SS, Pacheco T, Fanning S, Pages $J-M$, Amaral L. Identification of efflux pump mediated multidrug resistant bacteria by ethidium bromide agar cartwheel method. In vivo. 2011;25:171-8

10. Cheesebrough M. Escherichia coli District laboratory practice in tropical countries, Part 2. 2nd ed. London: Cambridge University Press; 2006. p. 178-80.

11. EUCAST. The European Committee on Antimicrobial Susceptibility Testing. Break point tables for interpretation of MICs and zone diameters version 9.0. 2019; http://www.eucast.org. Accessed 10 July 2019.

12. Stephanovic S, Vukovic D, Dakic I, Savic B, Svabic-Vlahovic B. A modified microtiter-plate test for quantification of staphylococcal biofilm formation. J Microbiol Methods. 2000;40(2):175-9.

13. Vuotto C, Longo F, Balice MP, Donelli G, Varaldo PE. Antibiotic resistance related to biofilm formation in Klebsiella pneumoniae. Pathog. 2014:3:743-58.

14. Calfee DP. Recent advances in the understanding and management of Klebsiella pneumoniae [version 1; referees: 2 approved]. F1000 Res. 2017;6:1760.

15. Soge OO, Queenan AM, Ojo KK, Adeniyi BA, Roberts MC. CTX-M-15 extended-spectrum (beta)-lactamase from Nigerian Klebsiella pneumoniae. J Antimicrob Chemother. 2006;57(1):24-30.

16. Otajevwo FD. Urinary tract infection among symptomatic outpatients visiting a tertiary hospital based in Midwestern Nigeria. Glob J Health Sci. 2013:5(2):187-99.

17. Akinduti PA, Olasehinde GI, Ejilude O, Taiwo OS, Obafemi YD. Fecal carriage and phylodiversity of community acquired bla TEM Enteric bacilli in Southwest Nigeria. Infect Drug Resist. 2018;11:2425-33.

18. Oli AGN, Ogbuagu VI, Ejikeugwu CP, Iroha IR, Ugwu MC, Ofomata CM, Okeke KN, Emechebe GO, Okoro JC, Okani CO, Onah SK. Multi-antibiotic resistance and factors affecting carriage of extended spectrum $\beta$-lactamase-producing enterobacteriaceae in pediatric population of enugu metropolis, Nigeria. Med Sci. 2019;7:104.

19. Huai W, Ma QB, Zheng JJ, Zhao Y, Zhai QR. Distribution and drug resistance of pathogenic bacteria in emergency patients. World $\mathrm{J}$ Clin Cases. 2019:7(20):3175-84

20. Yazdansetad S, Alkhudhairy MK, Najafpour R, Farajtabrizi E, Al-Mosawi RM, Saki M, Jafarzadeh E, Izadpour F, Ameri A. Preliminary survey of extendedspectrum $\beta$-lactamases (ESBLs) in nosocomial uropathogen Klebsiella pneumoniae in north-central Iran. Heliyon. 2019;5:e02349. 
21. Humayun A, Siddiqui FM, Akram N, Saleem S, Ali A, Iqbal T, Kumar A, Kamran R, Bokhari H. Incidence of metallo-beta-lactamase-producing Klebsiella pneumoniae isolates from hospital setting in Pakistan. Int Microbiol. 2018. https://doi.org/10.1007/s10123-018-0006-1.

22. Szabo O, Kocsis B, Szabo N, Kristof K, Szabo D. Contribution of OqxAB Efflux Pump in Selection of Fluoroquinolone-Resistant Klebsiella pneumoniae. Can J Infect Dis Med Microbiol. 2018. https://doi. org/10.1155/2018/4271638.

23. Maurya $N$, Jangra $M$, Tambat $R$, Nandanwar $H$. Alliance of efflux pumps with $\beta$-Lactamases in multidrug-resistant Klebsiella pneumoniae isolates. Microb Drug Resist. 2019;25(8):1155-63.

24. Nirwati H, Sinanjung K, Fahrunissa F, Wijaya F, Napitupulu S, Hati VP, Hakim MS, Meliala A, Aman AT, Nuryastuti T. Biofilm formation and antibiotic resistance of Klebsiella pneumoniae isolated from clinical samples in a tertiary care hospital, Klaten, Indonesia. BMC Proc. 2019;13:20.

25. Alcántar-Curiel MD, Ledezma-Escalante CA, Jarillo-Quijada MD, Gayosso-Vázquez C, Morf-n-Otero R, Rodr-guez-Noriega E, CedilloRam-rez ML, Santos-Preciado Jl, Girón JA. Association of antibiotic resistance, cell adherence, and biofilm production with the endemicity of nosocomial Klebsiella pneumoniae. Biomed Res Int. 2018. https://doi. org/10.1155/2018/7012958

\section{Publisher's Note}

Springer Nature remains neutral with regard to jurisdictional claims in published maps and institutional affiliations.
Ready to submit your research? Choose BMC and benefit from:

- fast, convenient online submission

- thorough peer review by experienced researchers in your field

- rapid publication on acceptance

- support for research data, including large and complex data types

- gold Open Access which fosters wider collaboration and increased citations

- maximum visibility for your research: over $100 \mathrm{M}$ website views per year

At BMC, research is always in progress.

Learn more biomedcentral.com/submissions 